\title{
The role of information technologies in the development of school social education practice
}

\author{
Natalia L. Selivanova ${ }^{1, *}$, Irina A. Tagunova ${ }^{2}$ \\ ${ }^{1}$ ISED RAE, Center of Strategy and Theory of Personality Upbringing, 105062, Moscow, Russia \\ ${ }^{2}$ ISED RAE, Comparative Education Center, 105062, Moscow, Russia
}

\begin{abstract}
The paper discusses various ways and specifics of applying information technologies in the process of school students' social education and reveals the role of IT in the development of the student's personality. Special attention is paid to the social education potential of network communities, the internet, virtual museums and mobile technologies. The paper also explains the risks of information technologies in social education.
\end{abstract}

A major social education problem, which needs its timely solution, is to identify changes which will enable a child, teenager or a young man to realize their personality growth according to their current social environment.

It should be noted that not all subjects of the presentday socialization and social education properly achieve their goals. It refers both traditional subjects (family, school, teachers, children's communities and collectives) and the subjects recently making themselves known very loudly (religious organizations, children's public organizations, youth subculture communities).

However, it has been proved that the above subjects possess a significant social education potential [1].

We must also admit that enormous positive experience has been accumulated in solving social education problems among its various participants, but it has either not attracted much publicity or still remains unclaimed.

Besides, possibilities to renew social education in Russia are also related to the transformation of the modern system of teaching including the development of open education, active use of IT and appearance of new teaching technologies.

Thus, we are witnessing the current situation which, on the one hand, calls for social education transformation while, on the other hand, it opens new opportunities for the development of both theory and practice of social education.

It should be pointed out that it is possible to achieve changes in the social education system only if there is a new attitude to it.

Let us look at the social education opportunities which are closely related to the renewal of such part of educational process as teaching.

Nowadays, the intensive development of open education may carry special significance for personality growth at any age. The principles of open education (open planning, opportunity to offer individual learning programs, free choice of place, time and pace of learning, transition from the "education for the whole life" principal to "education through the whole life", shift from the principle of "students moving towards knowledge" to the opposing principle of "knowledge delivered to students", and freedom to develop people's individualities) create the unique circumstances to build such vital human characteristics as independence, enterprise, initiative, responsibility, self-sufficiency and critical thinking [2].

Meanwhile, open education also poses certain challenges in social education as the former takes place mostly without direct contact either between students (while this is an important foundation of social education) or between the student and the teacher. Consequently, it is necessary to find ways to compensate for this lack of direct interaction in social education. In other words, open education needs a modified format of social education.

Active use of project-based teaching, as well as didactic and imitational games, may not only update conventional teaching methods but also contribute to the development of students' critical thinking, creativity, and self-reflection.

We are currently witnessing the intensive spread of IT and, primarily, into education. Today there is no need to convince anybody that IT may dramatically modify the educational process by creative new opportunities for children or young people's personality development [3]

Penetration of IT into social education looks much more modest. However, researchers have already shown their potential to renew the social education process.

It is only right that a large part of research is devoted to change patterns in children's personality related and other characteristics due to the spread of IT into all spheres of children's activity (T.P. Avdulova, G.I. Arkadyev, S.V. Bondarenko, A.E. Voyskunskiy,

* Corresponding author: nselivanova2000@mail.ru 
I.S. Kon, N.G. Marchenkova, T.D. Martsinkovskaya, L.O. Perezhogin, V.A. Pleshakov, A.Yu. Prigorov, G.V. Soldatova, N. Taranova, and others.).

J. Palfreyand and U. Gasser stress that children, who they call the generation of digital natives, spend a large part of their life on the World Wide Web and often do not distinguish between their life in the net and outside. They employ different ways of interaction with the information and are increasingly using the net space to obtain practically any information they need; they have different mechanisms of identity formation and a different perception of their reference community [4].

It is becoming more obvious today that the presentday educators deal with the $\mathrm{Z}$ generation children (born in 2006/7-2020) which reveal increased individualism, high self-esteem, infantilism, lack of peer socialization, distrust to the experience of other people, multitasking abilities, clip thinking, mosaic thinking and immersion in gadgets (L. Mazurik, Yu. Fukulova and others.) [5]. It is of no doubt that the above characteristics of children and teenagers have been caused, to a large extent, by letting IT become a part of their life.

Only if we are well aware of all the changes which take place in the growing generation, we may try to integrate IT into the process of social education.

Let us consider a few ways to apply IT in the contemporary school social education practice.

First of all, we must point to various social, art and local lore projects. Their realization requires diverse web resources which help, firstly, to find necessary information and, secondly, to establish interaction of project participants via social networks, e-mail, chats and Skype so that project teams are created to plan and carry out the project as well as track its progress. Such projects often become international. A project provides opportunities for cognitive and social activities, shapes the participants' communicative skills, independence and ability to work in a team, positive social activity-based experience. Quite often projects contain a moral part, and their results bring real benefit to people. This is especially true of social projects which shift from virtual to material reality.

Social education practice has accumulated extensive experience of using IT in art and aesthetic education. The potential of such technologies are truly enormous.

Virtual museums have recently become increasingly popular. It is known that «a virtual museum contains digital information about a museum which exists either in reality (museum web sites) or in the virtual net space. It is typical of virtual museums to employ interactive options offered by digital media: users may "travel" about the 3D halls, obtain any information and images, and make their own collections and exhibitions. An important ingredient is a constant feedback [6]. Two key types of virtual museums are of special importance to social education. The first type is official virtual museums. The second type is museums created by various educational institutions. Both of them have got new tools for social education of the young generation.

Apart from increasing students' cultural level, they create unique opportunities to shape young people's values, which is especially important on the current stage of the social development in Russia.

The main educational effect of a virtual museum is linked with its interactivity. One way of work with students is to conduct a virtual guided tour with interactive elements. Guided tours, as a tool to widen students' outlook and encourage their cognitive activity, have long been considered to be a powerful social education aid. Virtual tours make it possible to employ diverse materials of such museums as their exhibits may be prepared not only by teachers but also students. The latter may be offered to act as tour guides in an interactive mode or to make creative assignments in cooperation with teachers. A virtual tour may also serve as a basis for a social project, for example, aimed at children with disabilities or career orientation [7].

The use of virtual museums and tours is not limited to art and aesthetic education.

They may be fruitful in local lore and scientific activities or be very important in teaching patriotism.

Of course, school virtual museums offer special opportunities for social education. Recently their number has shown an increasing growth. They may be of different types. Such museums mostly deal with local lore history and culture focusing on the place where the educational institution is located. Besides, they may be devoted to the history of school or World War II.

The "Online School Museums" project, launched in 2005 , contributed to the development of such museums and promoted them in the internet community.

Students and teachers may work together to create virtual funds and electronic catalogues. Here students are not limited to the funds of the real museums. Besides, students may develop original ways to display school exhibits. Various informational technologies are invaluable in achieving this goal.

Another way to apply IT is to organize the museum's publishing and printing activities: to create catalogues and subject-based selections to be later used for classes and extracurricular work.

School museums may be used as a starting point to launch net projects which may involve teachers, students and parents of other schools as well as the staff of various cultural and social institutions. In small communities (a small town, municipal district or a village), such projects may contribute to a better social education space.

Students' activity in a school museum, equipped with IT, develops young people's active civic position, communicative skills, and emotional sphere by exposing students to history and culture. Such museums are extremely important in forming students' IT culture, which develops their creativity, independence, cognitive motivation and IT skills, as well as students' ability to obtain, analyze and assess information.

A school museum, equipped with IT, helps to create a special learning and moral education environment of the school. It gives birth to new organizational forms of students' cognitive and communicative activities. This transforms the museum from a storage place into a basis for students' active independent activity and promotes new forms of students' interaction with teachers. 
Application of IT in the educational environment of a school creates special conditions for social education. The key elements to achieve this include the regularly updated school web site, sites or pages of individual forms; online newspapers, magazines and videos primarily devoted to the life of the school (form); organization of after-school activities mediated by a computer club, which may have various goals, forms (e.g. computer chess club, programmers' club) or age groups.

Mobile technologies have become increasingly widespread recently. Many teaching aids contain various assignments for students to use QR codes or mobile gadgets including smart phones and tablet PCs. Such codes are known to be already widely used in museums and tourism.

The work of Baumanskiy Lyceum (Yoshkar-Ola, Russia) may be used as an illustration. The faculty has developed a teaching aid for extracurricular activities for students in grades 1 through 11 [8]. It contains "live" quests for students (educational games and activities) and teachers (professional development quests and various teaching aids). The assignments and video courses are encoded in QR codes and involve using teachers and students' mobile gadgets. The key element is each quest is some educational event defined as "a specially designed activity for children aimed at conscious and intentional acquisition of new experience, which later turns into a tool to achieve a new, higher goal" [8].

Such assignments are of diverse nature. They include the following projects: participation in the work of an expert board to approve the design of a playground (design and create a model of the "Childhood Palace" in one of the known architectural styles), authored by students of grade 7; a dispute entitled "Gadgets in the educational process" including a Google survey, authored by students of grade 11; an English language walking tour to see the newly-erected buildings of the native city of Yoshkar-Ola, Russia, authored by students of grade 4; the "Porridge" game (health benefits of a simple porridge), authored by students of grades 1 and 2; the "Mari national cuisine" culinary show, authored by girls of grade 8 and teachers; "School of intellect" classes (to prepare students for subject-based contests of different levels), authored by students of grade 11 [8].

Various gadgets and applications are used to complete the above and other similar activities. Realization of each assignment is split into 5 steps: educational idea, team planning, team preparation, assignment completion, and results analysis including reflection on the efficiency of the employed IT. The completion of a project is often followed by a workshop for teachers and parents. All this helps to integrate conventional creative group teaching methods and informational technologies thus ensuring thoroughly modified methods of social education.

It should be noted that IT may be widely used in class by supervising teachers in all their forms. First of all, we must point out the increasing popularity of class websites. Apart from the general information about the class, such websites may also post online discussions on important issues for students, provide the supervising teacher's direct communication with students and parents, display activity plans and reports of the past events, keep the record of the class history, post creative works of the supervising teacher, students and parents, organize contests, offer surveys for students and parents.

Class events may actively involve various media including video clips and audio recordings. Project results may be presented in the form of video films or clips, digital photos, school or class virtual newspaper or magazine, and a school radio program. These media offer a wide range of opportunities and depend on the imagination of students, teachers and parents.

Creation of a virtual environment in a modern educational institution is of a great importance for social education space.

Social educational space is defined as environment which serves as a mechanism to hold a certain event (L.I. Novikova, N.L. Selivanova, D.V. Grigoryev0 [9].

Meanwhile, the event is considered in two ways: as a "co-existence" of children and adults, and in terms of the event-related concept of the psychological time, according to which the specifics of human psychological perception of time, its pace, density and length depend on the number and frequency of events which take place in life - changes in the outer environment (natural and social), in the man's inner world (thoughts and emotions) as well as in human acts and deeds (E.I. Golovaha, A. A. Kronnik0 [10].

Essentially, environment is reality rather than the result of constructive activity. Social education space is the result of activity and, apart from being constructive, it is, and what is especially important, also integrative.

In this case, we must first focus on creating various network communities based on a given educational institution.

Network communities are known to be extremely popular nowadays. Many teenagers, high school students and teachers are among their members.

It is in network communities where school students are most likely to face negative phenomena: trolling, cyber bulling and cyber harassment [11].

No matter how old they are, school students are often unable to resist such negative factors. That is why educators are developing a new type of pedagogical research, child's safety, which, in particular, studies the problems of online safety [12].

According to I.S. Kon, another problem is that teenagers often do not separate their own online and real identities. As a result, many of them put in their real personal data. They are trying to turn their virtual contacts into real. This undoubtedly presents a certain danger or risk.

Quite often the criticism of network communities implies lack of meaningful communications in them, especially among teenagers.

School-based network communities may partially compensate for this lack by establishing various net interest groups of students. Such interests include hobbies, career-oriented preferences, various projects and mutual advisory help in different subjects or problems. 
Network communities may be created within the existing real world clubs, students' scientific societies, school museums and other youth communities.

Network communities contribute in building students' tolerance and critical thinking towards somebody else's opinion, other culture, and a man from a different social layer. They also help to develop students' skills of virtual and real world team working.

Nowadays, there is an increasing number of research related to the internet opportunities, especially in education [13, 14]. Some of that research also studies issues of social education related to controlled and uncontrolled use of the internet. If we speak about internet as some kind of educational resource, we must emphasize a number of its advantages making it a valuable source of knowledge for a modern school student. They include a great number of various resources for learning in all possible subjects represented in many forms (video materials, games, etc.), communication and consultations with teachers all over the world, interactive learning with elements of self control, freedom of time, pace and place of learning, individual study programs, and online communication with "classmates".

Results of the 2012-2013 research conducted by the Internet Development Fund and the Moscow State University Department of Psychology with support of Google (1203 respondents, aged 12-17 from 58 cities with the population over 100,000 and from over 8 federal districts) revealed 5 types of internet users among teenagers: "learning oriented", "communicators", "online readers", "gamers" and "universalists". The above types were identified according to the respondents' priorities in the virtual space [15].

In terms of social education, there are other interesting data obtained by the researchers. The teenagers were asked about the roles they assume online: "creator" (creating something new for themselves and others), "defender" (defending their own opinion and views, protecting themselves and others), "troll" (criticizing and attacking others whose opinion is different), "mentor" (helping others to learn something, including the ways how to act online), "mediator" (connecting people to each other), "observer", "interlocutor", "actor" (assuming certain roles), "manipulator" and "friend". According the researchers, teenagers are more active online than their parents, and the former are more likely to choose an active position. The researchers attribute this to the fact that the internet offers young people more opportunities for selfexpression [15].

As for the uncontrolled internet use in terms of social education issues, the first place was given to the problem of internet addiction.

N.V. Vostroknutov and L.O. Perezhogin point to a number of main symptoms of the internet addiction. Among them are: "1) excessive and unmotivated abuse of time spent online not related to professional, research or other productive activity; 2) internet services are used as the primary means of communication; 3) creation and utilization of virtual images which are far from real characteristics; 4) attraction to online games and development of computer viruses (without any particular purpose); 5) personally perceived impossibility to live without the internet" [16].

Moreover, teenagers and young people spending time online face various risks such as communication risks (cyber bullying, sexual harassment, random meetings), content risks (extremist and porno sites; sites which promote drugs, suicide; sites which explain how to create weapons); technical risks (spam, online trade, identity theft) and, finally, internet addiction [11].

Cyberspace socialization also takes place through acquisition of the social experience by means of absorbing social myths, adopting behavior patters, social navigation rules, norms, values and preferences of a particular network community as well as adopting interaction requirements of the cyberspace at large [17].

As for the use of IT in creating a school social education space, it is very important, in addition to the above network communities (social education space is always related with communications), to have school or class websites, TV and radio studios, in which students create various media products for school including those of informational, learning and social nature (video clips, presentations, photo films), and collections of creative works. It is also important to have a number of school students' associations which use IT in their activity.

The Intranet may be another positive factor in creation of the school social education space.

Certainly, all the above requires much effort (primarily from teachers) and funds.

Undoubtedly, the teacher plays a significant role in applying IT for the purpose of social education. Apart from being skilled in IT, the teacher must be highly motivated to use these technologies and understand their possible limitations and risks. This all means increased workload on the teacher.

Information technologies are becoming increasingly integrated in the sphere of education. So teachers must try to make IT be their helpers.

\section{References}

1. Polisubyektnost' vospitaniya kak uslovie konstruirovaniya social'no-pedagogicheskoy real'nosti (koncepciya), (URAO «ITIP», Moscow, 2009) [In Rus]

2. Ciklopediya, Available online: URL http://cyclowiki.org/wiki/ (accessed on: 12.02.2016) [In Rus]

3. I.A. Tagunova, Izvestiya Rossiyskoy akademii obrazovaniya, 4 (2009) [In Rus]

4. J. Palfreyand, U. Gasser Understanding the First Generation of Digital Natives, (EKSMO, Moscow, 2011) [In Rus]

5. Yu. Fukolova, Igrek neizvestnyy, Sekret Firmy, available online: URL http://www.kommersant.ru/doc/2483995 (accessed on: June, 2014) [In Rus]

6. Rossiyskaya muzeynaya ehnciklopediya, available online: URL 
http://www.museum.ru/rme/sci_virt.asp?1 (accessed on: 17.01.2016) [In Rus]

7. K.E Gribanova, Profil'naya shkola, 3, (2009) [In Rus]

8. Obrazovatel'noe sobytie "Bol'shaya sovetskaya ehnciklopediya» - novoe PRO-chtenie. ("Mariyskiy institut obrazovaniya", Yoshkar-Ola, 2015) [In Rus]

9. N.L. Selivanova, Pedagogika, 6, (2000) [In Rus]

10. E.I. Golovaha, A.A. Kronnik, Psihologicheskoe vremya lichnosti (NPF Smysl, Moscow, 2008) [in Rus].

11. G.V. Soldatova, Sovremennaya biblioteka 7, 27 (2012) [in Rus].

12. I.S. Kon, Sem'ya i shkola, 7 (2010) [in Rus].

13. V.A. Pleshakov, Teoriya kibersocializacii cheloveka (Homo Cyberus, Moscow, 2011) [in Rus].

14. A.V. Mudrik, Socializaciya cheloveka: ucheb. Posobie (MPSI, Moscow, Voronezh, 2010) [in Rus].

15. G.V. Soldatova, E. I. Rasskazova, and E. Zotova, Deti v informacionnom obshchestve, 15 (2013-2014) [in Rus].

16. N.V. Vostroknutov, L.O. Perezhogin, Prakticheskaya medicina, 6 (2009) [in Rus].

17. S.V. Bondarenko, Model' socializacii pol'zovateley $v$ kiberprostranstve, Tekhnologii informacionnogo obshchestva, Internet $i$ sovremennoe obshchestvo (SPbGU, St.Petersburg, 2003) [in Rus]. 